\title{
The changing role of housing assets in post-socialist countries
}

\author{
Srna Mandič
}

Received: 4 May 2009/Accepted: 28 January 2010/Published online: 24 February 2010

(C) The Author(s) 2010. This article is published with open access at Springerlink.com

\begin{abstract}
The paper discusses the ways and the extent to which home ownership in postsocialist societies represents a potential to serve as an additional source of welfare. First, the specific institutional context is observed, highlighting how during transition collectivist forms of welfare and housing provision gave way to more individualised risks coverage, thus strengthening the role of wealth and establishing home ownership on a massive scale. Secondly, the actual possibilities of home ownership to serve as a latent wealth reservoir are observed. To highlight the capacities and limitations of home ownership to sustain, store and release wealth, selected characteristics of households and of their housing are empirically examined by using data from EQLS. A relatively high incidence of unfit housing and of economic hardship and deprivation were found among homeowners, indicating their very limited capacity to store and sustain the wealth contained in their housing. This is particularly pronounced in comparison to West Europe. However, significant diversity was found also among post-socialist countries, as distinguished in three sub-groups; in the Central East European sub-group, the limitations were found distinctively less frequently.
\end{abstract}

Keywords Home ownership · Post-socialist countries · Wealth · Unfit housing · Deprivation

\section{Introduction}

In Western developed countries the role of housing assets in the provision of welfare has a long-standing tradition, and there is growing interest in this issue among social scientists (see Doling and Elsinga 2006; Ronald 2007). Households' assets in general, and the owneroccupied housing in particular, are increasingly seen as a wealth reservoir from which equity can be released and used as an additional resource for the provision of welfare in old

\footnotetext{
S. Mandič (ه)

Center za proučevanje družbene blaginje, Inštitut za družbene vede, Fakulteta za družbene vede, Univerza v Ljubljani, Kardeljeva pl. 5, 1000 Ljubljana, Slovenia

e-mail: srna.mandic@fdv.uni-lj.si
} 
age. This is also an important policy issue, as the financial sustainability of the pension and health insurance systems is coming under pressure due to the demographic ageing of the societies.

The possibility to use housing assets as a supplementary source for welfare is also becoming increasingly relevant for post-socialist countries, where the pressures of an aging population are considerable and where public welfare budgets have been substantially reduced during the transitional period. Housing in these countries seems to represent a huge potential because home-ownership rates are very high in comparison to most Western countries. However, the withdrawal of equity from owner-occupied housing is far from a simple technical procedure to be uniformly applied; on the contrary, it is 'a socially and culturally framed process which varies over time and between contexts '(Ronald 2006, p. 133). Thus, to comprehend what kind of latent additional resources for welfare are embodied in owner-occupied housing in post-socialist societies, the specific social circumstances need to be considered.

This paper focuses on post-socialist countries and, considering their specific legacy in housing and welfare provision, discuses the ways and the extent to which home ownership represents a potential to serve as an additional source of welfare in old age. The aim of the paper is to provide more detailed insight into how this potential has been shaped by specific social circumstances and how it is currently limited. To help understand and estimate it, this potential ability of home ownership is analysed from two perspectives. The first is the institutional context of welfare and housing provision. Previous collectivist forms of welfare provision diminished during the transition from socialism and, by giving way to more individualised risks, their coverage also strengthened the role of housing in storing and releasing of wealth. The second is the perspective of households and their dwellings. It considers their actual capabilities and limitations to store and release wealth for old age.

The structure of the paper is as follows. The first section deals with the institutional context of welfare provision and the corresponding role of housing in general and home ownership in particular. Meanwhile, it gives a historical account of the changes that occurred during the transition from socialism and that presently characterise post-socialist countries.

The second section sets forth an empirical analysis of selected characteristics of households and their housing, narrowing in on their actual capacities and limitations for using owner-occupied housing as a wealth reservoir for old age. The indicators were selected from the European Quality of Life Survey. Comparisons are made not only between the post-socialist countries and other EU member states, but also between subgroups to check for internal differences among the post-socialist countries. Finally, in the concluding section, the findings from both preceding sections are brought together and discussed.

\section{The changing institutional contexts of housing and welfare provision}

Under socialism, the nature of home ownership, its role in welfare provision and the system of welfare provision were quite specific. Distinguishing between the 'shelter' and the 'investment' (or property) function of housing (Smith 1971) it can be argued that in such a context the investment function of housing was minor while the shelter function was major. As shown below, this was sustained by two main institutional contextual factors: limitations on acquiring private housing property; and the universal collectivist welfare 
provision system. However, as further observed in this section, following the transitional reforms and other wider societal changes, the shelter function of housing was reduced and the investment (property) function of housing emancipated by a large-scale privatisation of housing assets.

\subsection{Under socialism}

In East and Central European socialist countries, in spite of considerable variation in public policies and in their institutional arrangements, a number of similarities could be found in housing. These commonalities constituted the East European Housing Model, for which Tosics and Hegedüs (1996) identified a number of distinctive features, recognising the existence of sub-models and variations (Hegedus and Teller 2006). These common features can be summarised under two conditions. Firstly, in the production, consumption and allocation of housing, the state dominated, while the functioning of the market was restricted and kept subordinate. Secondly, housing was defined primarily as a social right, serving to meet housing needs, and not as a commodity. In other words, it was the shelter function, not the investment (property) function, which was recognised as the supreme function of housing within this model. This was carried through in the housing system and the related public policies, whose arrangements were meant to enable a massive provision of state-supported rented housing, while tolerating - within certain limits - the privateproperty aspect of housing.

Public rented housing, implying a universal (i.e., non-exclusionary) accessibility by people in need, was at the forefront of the socialist housing model. Even the earliest and most popular criticism of its functioning was precisely about rented housing, most notably about its permanent shortages, long waiting periods and unequal access to it, favouring 'nomenclatura' (Szelenyi 1983). A high-quality rented dwelling at a good location was the symbol of prestige in those times, the attribute of the elite and one of its largest privileges (Mandič and Clapham 1996).

Parallel to the ideologically supreme rented housing, home ownership existed as well and was developed to a considerable extent (for a more detailed account see Turner et al. 1992; Clapham et al. 1996; Struyk 1996; Lowe and Tsenkova 2003). On the one hand, it has been generally subject to a number of restrictions. Among others, there were limitations on the size and particularly on the number of housing units; while generally a private person could legally own only one unit (with some exceptions made), it was often legally possible for a household to own two or three dwellings, particularly when the units had a different status such as vacation home or farm. On the other hand, there were different opportunities and ways to become a homeowner; besides the market, inheritance and here and there cooperatives, a very important mechanism was self-help construction. In some countries it was even strongly encouraged by employers and urban planning (Mandic 2001). Depending on how building materials and building land were made nationally and regionally available to private persons and on the scale of operation of the informal economy, in a number of countries individual self-help construction prospered at a substantial level. For instance, in the year 1980, of the total amount of new residential construction, it represented $37 \%$ in Hungary (Hegedus et al. 1996, p. 104), approx. 25\% in Poland (Muziol-Weclawowicz 1996, p. 228), approx. 50\% in Slovenia (Mandic and Stanovnik 1996, p. 152) and approx. 25\% in Bulgaria (Tsenkova et al. 1996, p. 101). In contrast, in the USSR, where the availability of building materials and building plots was much lower, self-help housing provision played only a minor role, at only $8 \%$ in 1980 (Kosareva et al. 1996, p. 267). 
With regard to the role of housing assets to serve as a welfare resource, it can be concluded that under socialism home ownership prospered to some extent, while other options for housing as private property were quite limited. Thus a substantial proportion of the population-particularly through extended family networks and in the form of vacation homes and farms - had some stake in housing assets and could directly or indirectly have some benefit from its use. Additionally, to a minor extent and occasionally, some material benefits could be obtained from its sale, letting to a relative or other person, or be otherwise used in exchange for resources. Thus, the role of housing assets in providing welfare under socialism cannot be denied, as these assets could substantially enhance the households' quality of life in different ways and in some instances even improve their material situation.

However, with regard to the entire social context, the role of housing assets in the provision of welfare represented only a minor addition. The formal robust welfare state provided services in housing, education, employment, health care, old age care and child care, generally at a moderate or even low level, yet still ensuring a universal basis. Under these circumstances, where social security, pensions and health insurance were guaranteed and unemployment and homelessness practically non-existent, the scope of individual risks was quite narrow, and it was even further lessened under the pressure of egalitarian principles. In socialist societies, with collectivist forms of welfare provision (Kemeny 1995), there was not much room in the formal system, nor were the individual incentives and resources present, for large-scale individual risk coverage. However, the prevailing egalitarian value orientations were very important.

\subsection{The transition and its outcomes}

The transition of socialist societies into the paradigms of the market economy and parliamentary democracy has been a complex and far-reaching process through which countries in Central and Eastern Europe started to radically alter in early 1990s. In each and every policy domain, including welfare and housing, new legal and institutional arrangements were introduced, leading to profound and unprecedented social changes and inspiring many debates among social scientists.

In housing, the logics and the intended outcomes of the transitional housing reforms can be most concisely summarised as a disintegration of the East European Housing Model (Hegedus and Tosics 1996; Hegedus and Teller 2006). Departure from this model implied that the market mechanisms and logics were given a more prominent role in the housing sphere, while the state's responsibilities, powers and resources were decreased. Resources previously earmarked for housing were cut radically: state budgets for housing investment and subsidies were reduced, the state property in housing stock was diminished by privatisation (sale to the sitting tenants) and, in some countries, by restitution to the original pre-war private owners or their heirs. These changes have been thoroughly examined by a number of analysts (see Turner et al. 1992; Clapham et al. 1996; Hegedus et al. 1996; Struyk 1996; Priemus and Mandic 2000; Buckley and Tsenkova 2003; Lowe and Tsenkova 2003; Cirman 2006; Hegedus and Teller 2007) and the steep increase in owner-occupation well documented. In short, a number of countries in the region turned into 'super home ownership' (Stephens 2004). In Hungary, Slovenia, Bulgaria and Romania, for instance, the rate of home ownership reached close to 90\% in 1994 (Hegedus, Mayo and Tosics 1996), three years after the transition had started.

Privatisation, which sometimes even occurred as 'give-away privatisation' (Hegedus and Teller 2007), and restitution were the key promoters of private property in housing. 
While justified as means to increase the economic efficiency of the housing system, they also enriched some citizens; no wonder 'the transfer of wealth from the government to the people was clearly popular' (Struyk 1996, p. 23). Privatisation and especially restitution of the rental stock have unleashed a massive (re)allocation of wealth and contributed to what Thurow (1997, p. 274) described as 'some initial distribution of the purchasing power', which is needed to start 'to play the capitalistic game'. Some analysts were quite critical about the outcomes of housing privatisation, pointing out its paramount wealth re-allocation effect. Kemeny (1995), in his powerful and profound analysis, bitterly characterised the housing reform outcomes in the region as 'a veritable orgy of asset stripping' and 'a fait accompli with barely any strategic policy debate' (1995, p. 149). In Slovenia, the supremacy of wealth allocation questions (i.e., 'who gets what, when and how') was reported in parliamentary debates on housing privatisation (Mandič 1994).

Anyway, wealth allocation was a significant by-product of housing reforms. In some cases, the gain in wealth was real and marketable (Sendi 2003). This was more often the case with restitution, where the expectations of economic gain were higher. Also the assets could be reclaimed on a larger scale-complete tenement buildings for instance. This might even lead to a complete change in social position and occupation of the claimant, who thus becomes a large-scale landlord. For private assets further possibilities for marketisation emerged after the protected tenant left such a dwelling, which could then be rented out or sold practically free of restrictions, even as commercial premises. On the other hand there were households who became homeowners through privatisation; for them, the gains in real terms, if any, varied substantially. Notable among the population that did not benefit from privatisation were the youth; as victims of lesser housing opportunities, they extended their stay in the parental home (Cirman 2007; Mandic 2008).

The questionable gain from privatisation is particularly apparent for poor homeowners, who have difficulty servicing their asset by paying the utility and maintenance costs. While these problems have been generally acknowledged in many post-socialist countries, they were thoroughly examined in the case of Hungary, where Hegedus and Teller (2006) reported a large proportion of households with problems of arrears in the fees for water service, heating, electricity etc. As housing-related costs increased much faster than real incomes, they became a burden and were perceived as one of the main risks among homeowners, as arrears might put them in danger of losing their home. Hegedus and Teller (2007) clearly pointed out how both the risk and the security aspect of home ownership became relevant. It can be concluded that with the transition, the property function of housing was unleashed, bringing not only benefits but also risks and burdens.

However, during the transition not only did the nature of housing assets change but so did the wider welfare policy context as well as the approach to welfare issues, thereby leaving more space for individual decisions, opportunities and risks. While the previous comprehensive welfare systems were under restructuring, new problems and new triggers of material deprivation appeared, such as unemployment, low-paid jobs and unsatisfactory pensions. Facing new problems and deprivations, the social security coverage often proved to be insufficient and to suffer from a delayed implementation of new social safety-net arrangements. Thus, with these new threats and triggers of deprivation, the need for new and additional sources of individual welfare is becoming significant, including housing assets. There is an obvious need and a great potential for wealth stored in housing, to be used as a complementary source of welfare not only in old age, but also earlier in life.

New social risks specific to post-industrial societies and aging populations (Bonoli 2006) are also relevant to post-socialist societies. When compared to the established EU member states, the new member states are, according to the report on the Social Situation 
in Europe 2004, undergoing similar demographic changes. Thus, in demographic trends and in social policy developments, including pensions and health care, post-socialist countries have many points of convergence with Western EU members (Manning 2004).

\section{Capacities of home ownership to serve as a wealth reservoir-an empirical account}

The new institutional context that gradually emerged through the period of transition made room for private wealth and housing assets to play a more prominent role as a supplementary source of welfare. In that regard, since home ownership had become a mass tenure, some have questioned the actual possibilities of households to store and later on use their wealth in housing. So it is pertinent to consider the quality and quantity of housingrelated resources that households dispose of and which could be potentially used for other welfare purposes. This implies not only housing assets but also the resources to keep and service these assets.

To gain insight into the capacity of home ownership to sustain, store and release wealth in post-socialist societies, this section empirically examines selected characteristics of households and of their housing. The analytical focus is on the possible limitations and shortcomings. The wider aim is to give an indication of what is specific to post-socialist countries in comparison to West European societies.

\subsection{Data, indicators and grouping of countries}

In our analysis we use data from the European Quality of Life Survey ${ }^{1}$ held in 2003, based on the nationally representative samples of population of 27 countries, now EU member states.

Given a long-standing general lack of comparable data for post-socialist countries (Roberts 2003; Manning 2004), this collection of data was selected. It is one of the very few that provide full coverage and comparability for all new member states and, moreover, contain information that is highly relevant for the topics analysed here.

The data from EQLS covers a wide range of topics. To explore the capacities of homeownership to serve as a latent wealth reservoir and to highlight their weaknesses, the following indicators were selected and organised under three topics.

- The rate of home ownership: It designates the relative size of the population and of the housing stock/assets that are involved when home-ownership is considered as a latent resource to be consumed. It should be pointed out that in line with the EQLS survey, home ownership refers to households and to their self-reported housing tenure, not to dwellings. Therefore, these data cannot be directly compared to other data sources, where home ownership refers to housing units.

\footnotetext{
1 The European Quality of Life Survey (2003) was carried out in the 15 EU Member States before May 2004 (EU15), the 10 acceding countries becoming new Member States in May 2004, and the 3 candidate countries (Bulgaria, Romania and Turkey). The questionnaire covered a number of life domains, such as working conditions, housing, family and other domains and provided fully cross-nationally comparable information. The population interviewed consisted of adults, aged 18 years and over, who were residents in the 28 countries in 2003. A multi-stage stratified random sampling procedure was used. 1,000 interviews were conducted in the larger countries, and 500 in the smaller ones. Data were collected in face-to-face interviews. Weighting variables were produced according to age, gender and region within the country.
} 
- Unfit owner-occupied housing: This composite indicator, combining several deficiencies as explained in detail later, stands for the quality of owner-occupied housing. Deficiency of housing suggests very indirectly also the wealth which is potentially stored in the dwelling; however, it also designates the insufficient capacity of households to sustain their wealth in housing by proper maintenance.

- Economic situation of homeowners: To observe this characteristic of households in owner-occupied housing the following indicators were selected: distribution across income quartiles; two composite indicators of material deprivation; and arrears in paying utility bills. These indicators, fully described later in the text, all designate the scale of economic hardship that homeowners face and that limit their ability to accumulate and sustain the wealth contained in their housing.

Grouping of countries for analytical purposes is another issue to be discussed. In an empirical analysis aiming to estimate the specific potential of home-ownership in postsocialist countries, a point of reference is needed to serve as a standard against which to evaluate the results of measuring. Thus, the comparisons take West European countries as a reference point and are not intended as a comprehensive cross-national comparison. However, as significant differences between post-socialist countries were found with regard to welfare provision (Kovacs 2002; Manning 2004; Lendvai 2004) as well as to housing (Hegedus et al. 1996; Lowe and Tsenkova 2003), differences between them should not go unnoticed.

Thus, to inspect the internal variation, post-socialist countries are classified into three sub-groups: North East European (NEE) with Estonia, Latvia, Lithuania and Poland; Central East European (CEE) with the Czech Republic, Hungary, Slovakia and Slovenia; and South East European (SEE) with Bulgaria and Romania. These groups are homogeneous in geographical terms, and have already, under somewhat different names, been used to monitor housing developments in the region (see Hegedus et al. 1996). In this analysis the only deviation from it is about Poland, which is not classified among the CEE but into the NEE because of the similarities found in the system of welfare provision (Mandic 2008).

The West European countries are further divided into four sub-groups, employing a classification that is in line with broadly accepted versions of typologies of welfare regimes (Allen et al. 2004; Berthoud and Iacovou 2004): Atlantic with UK and Ireland; Scandinavian with Denmark, Finland and Sweden; Continental with Austria, Belgium, France, Germany, Luxembourg and the Netherlands; and South European with Cyprus, Greece, Italy, Malta, Spain and Portugal.

The value of the indicators is calculated and expressed as a simple arithmetic un-weighted group average for each sub-group. Group averages are reported after being tested to be reasonably well representative of individual members. However, where specifically needed, attention is called to the 'outliers'.

\subsection{Home ownership rate}

Figure 1 depicts the group average ownership rates for each sub-group. Post-socialist countries and their three sub-groups all prove to represent 'super home ownership' housing systems (Stephens 2004; Hegedus and Teller 2006). While they all range between 74 and $87 \%$, the exceptions of Latvia and the Czech Republic should be noted as 'outliers' reaching significantly lower figures.

In terms of their home ownership rate the post-socialist sub-groups generally surpass the West European sub-groups. Yet their two sub-groups are precisely matched: the 


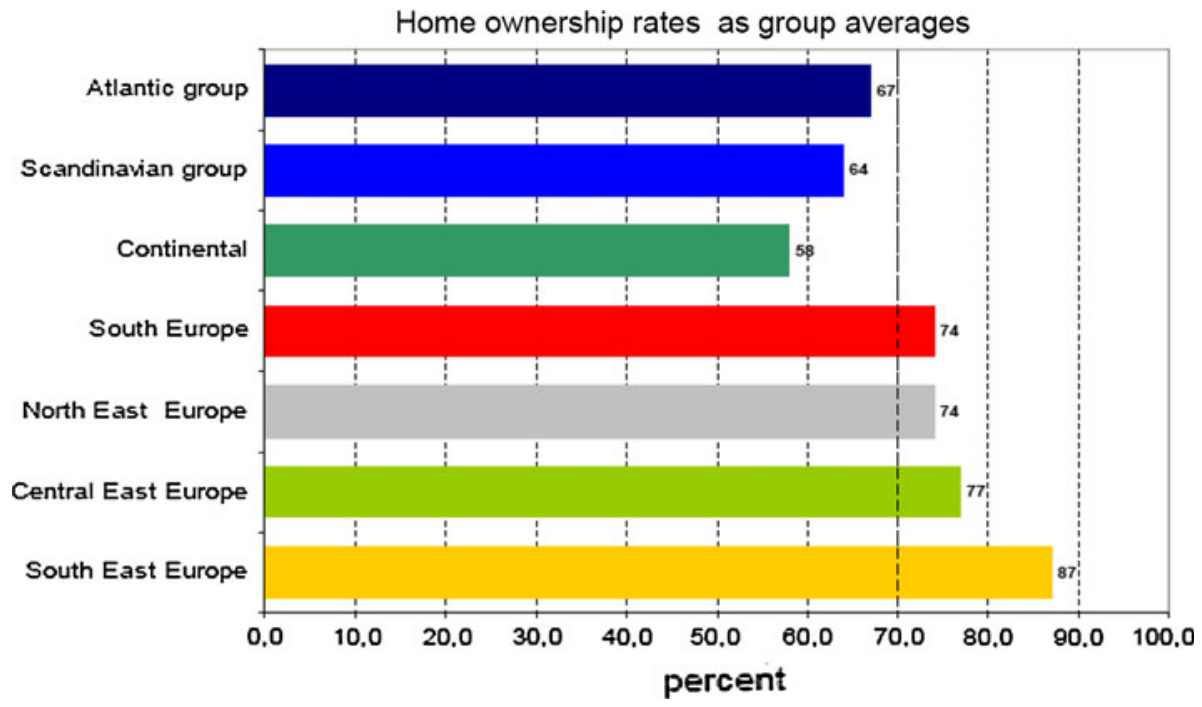

Fig. 1 Home ownership rates—group averages. Source: EQLS (2003)

home-ownership rate of the South European sub-group, being the highest in Western Europe, is identical to that of the North East European sub-group, being the lowest of the post-socialist set. The highest home ownership rate of all is found in the South Eastern group, reaching close to $90 \%$. Diversity among the post-socialist sub-groups is considerable and similar to that found for Western Europe.

\subsection{Unfit owner-occupied housing}

While housing property generally represents an accumulation of wealth and a valuable economic resource for the owner, it requires up-keep, maintenance and modernisation to remain in good condition. Poor housing conditions signify an inability of the owners to maintain the property and, as a consequence, lead to a depreciation in value. Moreover, urgent repair, needed to restore conditions to a tolerable level, might be a costly burden threatening the current welfare resources. Figure 2 depicts the incidence of unfit housing among homeowners. 'Unfit' designates housing having any of the following deficiencies: dampness and leaks; rot in windows, doors, floors; or lack of indoor flushing toilet.

The figures reveal the nearly dire situation in post-socialist countries; for two subgroups, with practically the majority of the owner-occupied housing stock is in a state of disrepair. In contrast, in three West European sub groups, unfit housing is reported by a minority of households, generally close to $10 \%$. Indeed, there is a striking disparity in the scale of unfit housing across Europe, indicating extremely diverse situations. However, apart form this general picture, the South European sub-group of Western Europe and the Central East European sub group of post-socialist countries take intermediary positions and are very similar to each other. It should be added that as a rule in all subgroups there is slightly less unfit housing among the homeowners than in the total population. 


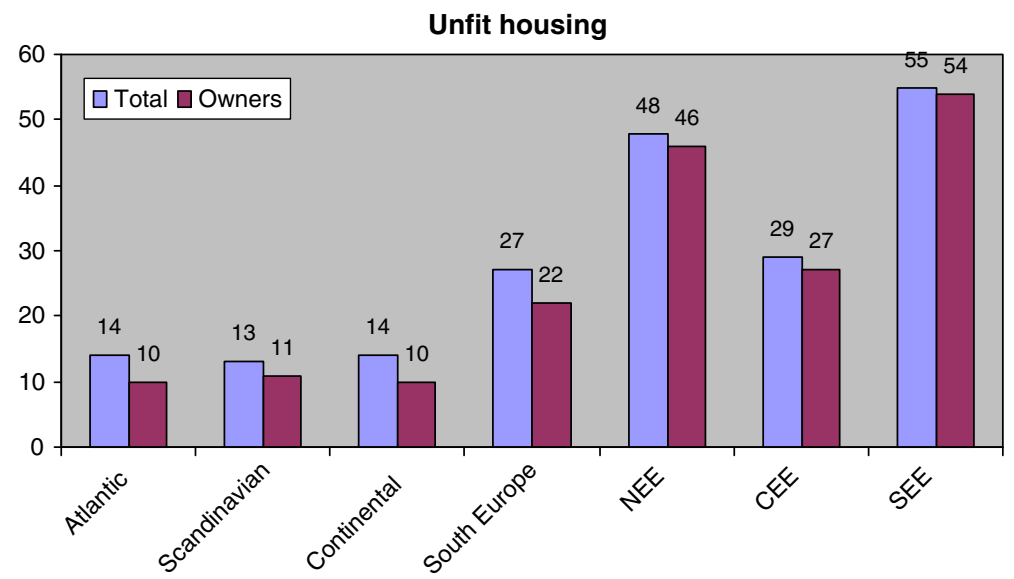

Fig. 2 Percentage of unfit housing* in total population and among homeowners, as group average. Note: *Unfit housing $=$ at least one of the following problems with accommodation: Shortage of space; Rot in windows, doors or floors; Damp/leaks; Lack of indoor flushing toilet

\subsection{Economic situation of homeowners}

Poverty, income and deprivation are phenomena that are difficult to observe and compare cross-nationally, as they are embedded in national social, economic and cultural contexts. Because the relation between economic situation and home ownership is multi-faceted and very complex, our intention here is to offer only the most rudimentary insight. We focus on five indicators, some of them the original indicators of the EQLS questionnaire, some derived from them.

The first indicator is the home ownership rate across income quartiles. In Fig. 3 the home ownership rates for income quartiles are presented as group averages. The basic expected trend is that with the rising income also the likelihood of home ownership rises; this would be manifested as the higher the income quartile, the higher the home ownership rate.

If home ownership can function as 'a badge of success' (Doling and Horsewood 2005), this is certainly not a general rule in post-socialist countries. In contrast to most of Western Europe, post-socialist countries do not demonstrate a clear relation between the income positioning of households and their housing tenure. This indicates a possibly strong impact of 'give-away' privatisation policies and also widespread self-help housing. Strongly developed self-help housing is also characteristic of the South European sub-group, which to some extent is similar to post-socialist countries with regard to the relation between income and home ownership.

Figure 4 presents four other indicators of the economic situation of homeowners. The first is the composite indicator of 'severe material deprivation', measured as the situation whereby households have run out of money to pay for food during the last 12 months. The incidence of such deprivation ranges between 7 and $43 \%$ for post-socialist sub-groups, indicating a rather strong presence of this phenomenon and also a large diversity between sub-groups. The incidence is much lower in Western Europe, where it ranges from 3 to $7 \%$ across sub-groups.

Another indicator of the economic situation, as presented in Fig. 4, is the incidence of a milder form of deprivation among homeowners. It is defined as an inability to afford any 


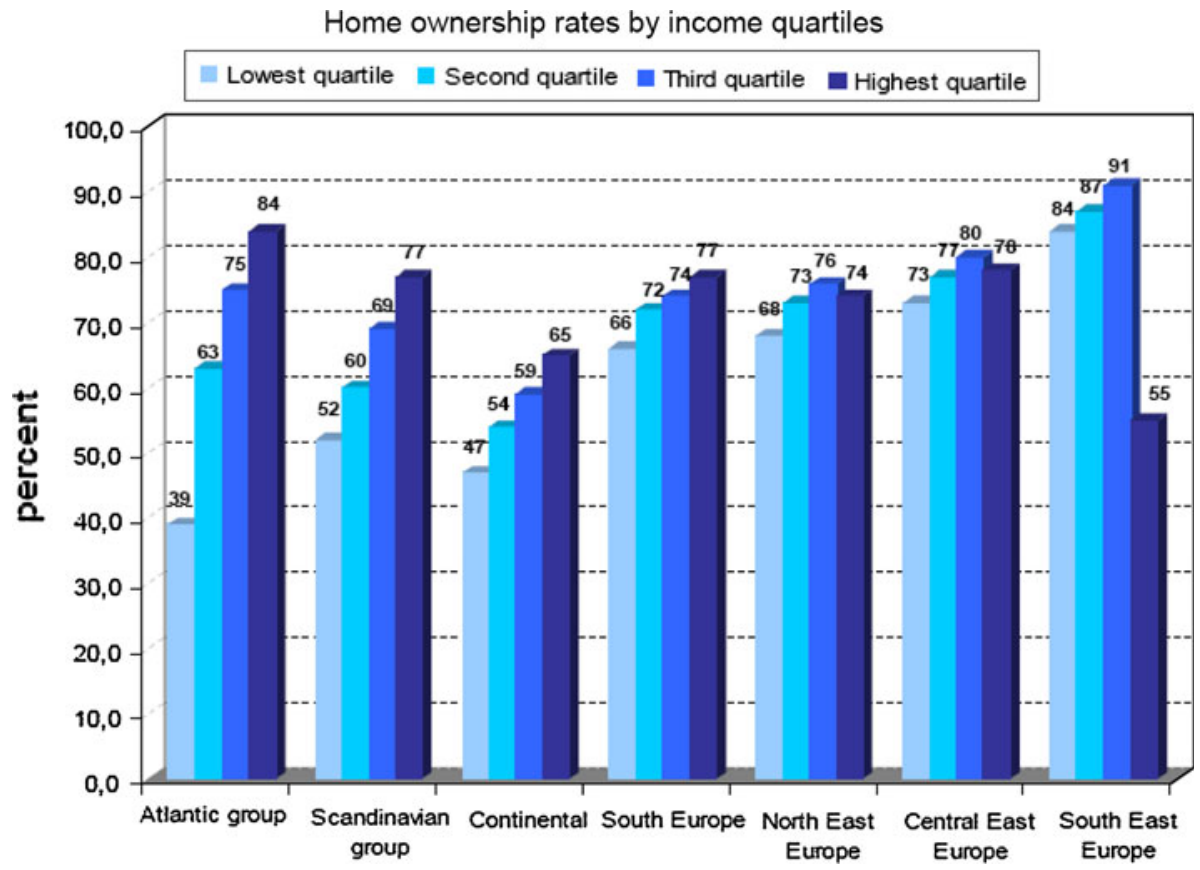

Fig. 3 Home ownership rate by income quartiles in seven groups. Source: EQLS (2003)

one out of a list of five consumer items. A very high incidence of mild deprivation is revealed among homeowners in the North Eastern and South Eastern sub-groups of the post-socialist groups, even above $80 \%$. It dramatically exceeds the figure of $20 \%$ found in three West European sub-groups. Again, in an intermediary position and rather close to each other lie two sub-groups: South European from the Western Europe group; and Central East European from the post-socialist countries.

'Arrears in utility bills' is another indicator of economic hardship that homeowners face. Again, according to empirical data, this problem is quite frequent in the three groups of post-socialist countries. Among them, again, it is lowest in the Central East European sub-group but the highest this time in NEE.

The last indicator is about an additional resource that households use to help meet their needs for food by growing fruit and vegetables or keeping poultry or livestock ('growing food'). Although these practices might include another intrinsic dimension and serve other motives, they also represent a significant coping strategy in post-socialist countries. Figure 4 shows that in three post-socialist sub-groups this activity is similarly very frequent and practiced even by the majority of homeowners. This practice is much less pronounced in Western Europe, not exceeding $20 \%$ of homeowners.

To sum up the results, a very high incidence of economic hardship was found among homeowners in post-socialist countries. It is particularly high compared to West European groups. However, also within post-socialist countries there is a substantial gap between the sub-group of CEE countries, on the one hand, and on the other hand NEE and SEE with significantly more pronounced limitations. 


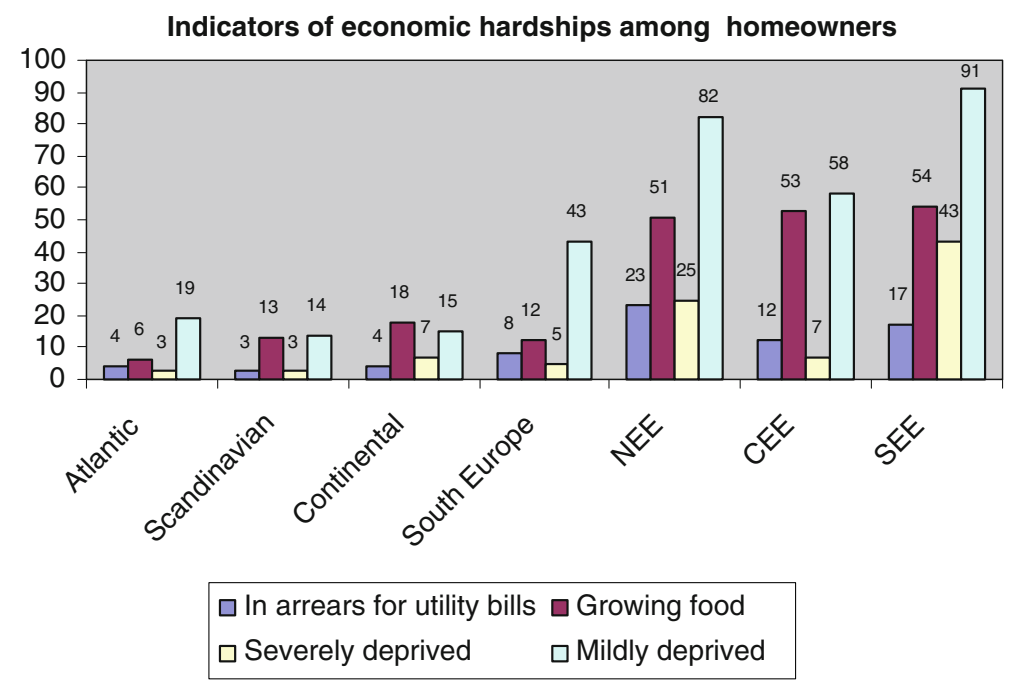

Fig. 4 Indicators of economic hardship among homeowners in groups of countries. Note: 'In arrears for utility bills' $=$ Households that have been in arrears at any time during the past 12 months, that is, unable to pay as scheduled the utility bills, such as electricity, water, gas'. 'Growing food' = 'Households that in the past year helped meet their need for food by growing fruit or vegetables or by keeping poultry or livestock'. 'Severely deprived' = Positive answers on question: Did the household run out of money to pay for food?". 'Mildly deprived' = Cannot afford at least one of the following: Keeping your home adequately warm; Paying for a week's annual holiday away from home; Replacing any worn-out furniture; A meal with meat, chicken or fish every second day if you wanted it; Buying new rather than second-hand clothes; and Having friends or family over for a drink or meal at least once a month. Source: EQLS (2003)

\section{Conclusions}

In this paper housing assets in post-socialist countries are examined with regard to their possible role in supplementing the public welfare systems. However, post-socialist countries have a quite specific legacy in both welfare and housing provision. It has been shown here how the property function of housing - though in specific forms and legally restricted-had already been basically developed under socialism, whereas the shelter function of housing was dominant both in ideology and in formal housing systems, with a focus on public rented housing. But then, the privatisation and restitution of housing, which formed the core of housing reforms in most socialist countries, further emancipated the property function of housing. These reforms created home ownership as a mass tenure and in a short period of time spread housing assets on a massive scale.

With the transitional reforms, the entire welfare system changed. Contrary to the robust, all-encompassing state-dominated welfare system under socialism, a new, thoroughly retrenched welfare system emerged, one that left considerable space for individual deprivation and risks. Under socialism, benefits based on housing assets could generally represent only a minor addition to those provided by the formal robust welfare state. But this has been radically altered, and many new generators of deprivation and insecurity have emerged and need to be dealt with individually. So there is more room-and greater need-for housing assets to be used in individual risk coverage and in individual welfare 
improvements. To what extent, thus, does home ownership represent a 'wealth reservoir' to be used by homeowners as a shield against these sources of deprivation and insecurity?

Empirical analysis of different characteristics and resources of homeowners in postsocialist countries has clearly shown that these potentials are very limited. Post-socialist countries, grouped in three sub-groups, on the whole exhibit a very high incidence of home ownership, thus practically personifying the 'super home ownership' phenomenon. However, unlike in most of Western Europe, the home ownership rate here does not clearly rise with the income quartile. Homeowners in post-socialist countries could hardly be pictured as the 'better-off' part of the population. Instead, this is a case wherein home ownership, as it becomes a mass tenure, would also 'take on more of the features of the unequal contours of the social structure' (Forrest and Murie 1994, p. 73). As figures on various indicators of deprivation in our empirical analysis have shown, homeowners in post-socialist countries experience material deprivation and hardship to a significant extent. The phenomenon of poor homeowners as 'cash-poor and asset-rich' (Hegedus and Teller 2006) is confirmed as being highly relevant throughout the region. However, there are huge differences encountered among the post-socialist countries as well. When the Central East European sub-group is compared to Western groups and particularly to Southern Europe, this difference is minor. Conversely, in the case of NEE and particularly of SEE, the difference is dramatic and vividly points out how European societies differ in the level of living. In the case of South Eastern Europe, both the West-East bias and the North-South bias seem to have joined and built up strength.

The incidence of unfit housing among homeowners has also been analysed. This indicator captures not only the wealth that is potentially stored in the dwelling but also the inability of households to sustain this wealth by proper maintenance and renovation. The analysis found it to be generally rather high in post-socialist countries, but particularly high in the sub-groups of NEE and SEE, where the majority of owner-occupied housing is reported to be unfit. The scale of this problem in selected countries has already been recognised by EU structural funds, thereby accepting the responsibility to deal with the problem. Homes in a state of disrepair and requiring investments represent a heavy burden, not simply an asset. That is why such homeowners should not be considered 'asset-rich' at all. They also have problems servicing their homes, notably arrears in paying utility bills, as reported by 12 to $23 \%$ of the homeowners. These figures, along with those on unfit housing, clearly suggest that both the risk-solving and the risk-generating potential of home ownership in post-socialist countries should be specifically recognised.

Acknowledgments The author is grateful to the UK Data Archive for granting permission to use data of the European Quality of Life Survey (2003) and acknowledges that the original data creators, depositors or copyright holders, the founders of the Data Collections and the UK Data Archive bear no responsibility for their further analysis or interpretation. The author is also grateful to two anonymous referees for their helpful comments. The paper is based on research conducted in the EU 7th Framework Programme DEMHOW and supported by the Agency for Research and Development of the Republic of Slovenia, PS P5-0200.

Open Access This article is distributed under the terms of the Creative Commons Attribution Noncommercial License which permits any noncommercial use, distribution, and reproduction in any medium, provided the original author(s) and source are credited.

\section{References}

Allen, J., Barlow, J., Leal, J., Maloutas, T., \& Padovani, L. (2004). Housing and welfare in Southern Europe. Oxford: Blackwell Publishing Ltd.

Berthoud, R., \& Iacovou, M. (Eds.). (2004). Social Europe. Cheltenham, Northampton: Edward Elgar. 
Bonoli, G. (2006). New social risks and the politics of post-industrial social policies. In K. Armingeon \& G. Bonoli (Eds.), The politics of post-industrial welfare states (pp. 3-27). London and New York: Routledge.

Buckley, R. M., \& Tsenkova, S. (2003). Housing reforms and market performance. In S. Lowe \& S. Tsenkova (Eds.), Housing change in East and Central Europe. Integration or fragmentation?. Aldershot: Ashgate.

Cirman, A. (2006). Housing tenure preferences in the post privatization period: The case of Slovenia. Housing Studies, 21(1), 113-134.

Cirman, A. (2007). Intergenerational transfers as a response to changes in the housing market. Paper at the ENHR research conference, Rotterdam.

Clapham, D., Hegedus, J., Kintrea, K., \& Tosics, I. (Eds.). (1996). Housing privatization in Eastern Europe. Westport, London: Greenwood Press.

Doling, J., \& Elsinga, M. (Eds.). (2006). Home ownership getting in, getting from, getting out. Amsterdam: IOS Press.

Doling, J., \& Horsewood, N. (2005). Housing opportunities and welfare provision: Testing causality. Housing, Theory and Society, 22(2), 80-83.

European Quality of Life Survey. (2003). Principal investigators were: European Foundation for the Improvement of Living and Working Conditions and Wissenschatszntrum Berlin Fur Sozialforschung, Data Collector: Intomart GFK (Hilversum, Netherlands), Sponsor: European Foundation for the Improvement of Living and Working Conditions; Distributed by UK Data Archive, University of Essex, Colchester; February 2006. SN: 5260.

Forrest, R., \& Murie, A. (1994). Home ownership in recession. Housing Studies, 9(1), 55-74.

Hegedus, J., Mayo, E., \& Tosics, I. (1996). Transition of the housing sector in the East-Central European countries. Budapest: USAID, Metropolitan Research Institute.

Hegedus, J., \& Teller, N. (2006). Managing risks in the new housing regimes of the transition countries-the case of Hungary (pp. 175-200). Amsterdam: IOS Press.

Hegedus, J., \& Teller, N. (2007). Hungary: Escape into home ownership. In M. Elsinga, et al. (Eds.), Home ownership beyond asset and security (pp. 133-173). Amsterdam: IOS Press.

Hegedus, J., \& Tosics, I. (1996). The disintegration of the East European housing model. In D. Clapham, J. Hegedüs, K. Kintrea, I. Tosics, \& H. Kay (Eds.), Housing privatization in Eastern Europe (pp. 15-40). Westport, London: Greenwood Press.

Kemeny, J. (1995). From public housing to the social market: Rental policy strategy in comparative perspective. London: Routledge.

Kosareva, N., et al. (1996). Russia: Fast starter- housing sector reform 1991-1995. In R. Struyk (Ed.), Economic restructuring of the former Soviet Bloc: The case of housing (pp. 255-306). Aldershot: Avebury.

Kovacs, J. M. (2002). Approaching the EU and reaching the US? Rival narratives on transforming welfare regimes in East-Central Europe. West European Politics, 25(2), 175-204.

Lendvai, N. (2004). The weakest link? EU accession and enlargement: dialoguing EU and post-communist social policy. Journal of European Social Policy, 14(3), 319-333.

Mandič, S. (1994). Housing tenures in times of change: Conversion debates in Slovenia. Housing Studies, 9(1), 27-38.

Lowe, S., \& Tsenkova, S. (Eds.). (2003). Housing change in East and Central Europe. Aldershot: Ashgate.

Mandic, S. (2001). Residential mobility versus "in-place" adjustments in Slovenia: viewpoint from a society "in transition". Housing Studies, 16(1), 53-73.

Mandic, S. (2008). Home-leaving and its structural determinants in Western and Eastern Europe: An exploratory study. Housing Studies, 23(4), 615-637.

Mandič, S., \& Clapham, D. (1996). Meaning of home ownership in the transition from socialism: The example of Slovenia. Urban Studies, 33(1), 83-97.

Mandic, S., \& Stanovnik, S. (1996). Slovenia: Fast privatization of the stock, slow reform of housing policy. In R. Struyk (Ed.), Economic restructuring of the former Soviet Bloc: The case of housing (pp. 139174). Aldershot: Avebury.

Manning, N. (2004). Diversity and change in pre-accession Central and Eastern Europe since 1989. Journal of European Social Policy, 14(3), 211-232.

Muziol-Weclawowicz, A. (1996). Polish housing in transition, 1990-1994. In R. Struyk (Ed.), Economic restructuring of the former Soviet Bloc: The case of housing (pp. 219-254). Avebury: Aldershot.

Priemus, H., \& Mandic, S. (2000). Rented housing in Eastern and Central Europe-No man's land? Journal of Housing and the Built Environment, 15(3), 217-231.

Roberts, A. (2003). Privatization and rent regulation in Eastern Europe. In S. Lowe \& S. Tsenkova (Eds.), Housing change in East and Central Europe. Integration or fragmentation?. Aldershot: Ashgate. 
Ronald, R. (2006). Convergence? Home ownership and asset-based welfare regimes. Paper at international workshop home ownership in Europe: Policy and research issues, Delft 2006.

Ronald, R. (2007). Comparing homeowner societies: Can we construct an east-west model? Housing Studies, 22(4), 473-493.

Sendi, R. (2003). An emerging private rental market in Ljubljana. In S. Lowe \& S. Tsenkova (Eds.), Housing change in East and Central Europe. Integration or fragmentation? (pp. 155-169). Aldershot: Ashgate.

Smith, W. F. (1971). Housing: The social and economic elements. Berkeley: University of California Press.

Stephens, M. (2004). Role of housing finance in the housing policy of the transition country. Paper on the workshop on housing finance in transitional countries; Budapest 2004.

Struyk, R. (1996). Economic restructuring of the Former Soviet Bloc: The case of housing. Avebury: Aldershot.

Szelenyi, I. (1983). Urban inequalities under state socialism. New York: Oxford University Press.

Thurow, L. (1997). The future of capitalism. London: Nicholas Barley Publishing.

Tosics, I., \& Hegedüs, J. (1996). Housing in South-Eastern Europe. In D. Clapham, J. Hegedüs, K. Kintrea, I. Tosics, \& H. Kay (Eds.), Housing privatization in Eastern Europe (pp. 169-189). Westport, London: Greenwood Press.

Tsenkova, S., et al. (1996). Bulgaria. In D. Clapham, et al. (Eds.), Housing privatization in Eastern Europe (pp. 97-118). Westport, London: Greenwood Press.

Turner, B., Hegedus, J., \& Tosics, I. (Eds.). (1992). The reform of housing in Eastern Europe and the Soviet Union. London and New York: Routledge. 